\title{
The Effect of Active Learning on Developing the EFL Speaking Skills of the Saudi Kindergarten Students in Saudi Arabia
}

\author{
AlJohara Fahad AalSaud \\ Assistant Professor in Kindergarten Education \\ College of Education \\ King Saud University
}

\begin{abstract}
This study aimed at investigating the impact of using a program based on active learning strategies on developing the EFL speaking skills among the Saudi kindergarten students in Saudi Arabia. The participants enrolled in the second level of kindergarten (KG2). The researcher hypothesized that if the students were given the communication opportunities and speaking in a classroom-based on active learning strategies, so their English speaking skills may be improved. In the same respect, the present study attempted to answer the following hypothesized question: Is there a statistically significant difference between the Saudi kindergarten students' mean scores on the English speaking skills test due to the teaching procedures of active learning strategies, or not? To answer the aforementioned question, the researcher designed a rubric for assessing the participants' speaking skills before and after implementing the program based on active learning strategies in speaking classes. A pre-post speaking skills' test, comprehended the dimensions of accuracy and fluency of English speaking skills in classes, was designed by the researcher and refereed by a jury of specialists in the field of education from different countries. The sample entailed 150 students from one of Al-Riyadh Kindergartens. Validity and reliability of the research instruments were validated. Results were calculated and discussed. Finally, recommendations and suggestions for further research were introduced.
\end{abstract}

Key words: Active Learning Strategies, Speaking skills, kindergarten students, Saudi Arabia, effect.

\section{Introduction and Background}

Speaking English is considered as one of the most fundamental skills to be mastered in language learning. It is supported by the fact that speaking proficiency is often used as the measurement of the success of learners in learning English (Hasan, 2014). Hedge (2000) defined speaking as "a skill by which people are judged while first impressions are being formed." (Hedge,2000).On the other hand, Chun(2006) defined speaking as "the act of talking to someone, of making an utterance with intentional and unintentional dealings, or of a discourse of a person who really speaks. It refers also to literary works and artistic communications that are composed of daily recitations, as ancient poetry and oral literature regardless of a language spoken by the people worldwide." (Chun, 2006).

The goal of teaching speaking skills is communicative efficiency. Learners should be able to make them selves understood, using their current proficiency to the fullest. They should try to avoid confusion in the message due to faulty pronunciation, grammar, or vocabulary, and to observe the social and cultural rules that apply in each communicative situation (Nunan, 2003).

Concerning speaking, it may be considered as a difficult skill to develop because of the students' lack of confidence, exposures and motivation (Febriyanti, 2011). Speaking skill is also viewed as challenging because the students need more time and courage to speak (Bashir , 2011; Oradee, 2012). In addition, some of the students are reluctant to speak because they feel nervous in expressing themselves in front of other people (Harmer, 2007).

Kayi (2006) proposed some principles of teaching speaking, for teachers to be implemented in classrooms such as; being aware of the difference between second and foreign language, giving students the chance to practice with fluency and accuracy, providing learners with opportunities to talk by using group and pair work and limit the teachers' talk, planning speaking tasks to involve negotiation of meaning, designing classroom activities that involve guidance and practice both transactional and interactional speaking, eliciting questions such as "What do you mean? How did you reach that conclusion?" in order to prompt students to speak more and provide written feedback like "Your presentation was really great. It was a good job. I really appreciated your efforts in preparing the materials and efficient use of your voice."

Concerning the importance of speaking, it is more revealed with the integration of the other language skills. For instance, it can assist learners to improve their vocabulary and grammar usage and then enhancing their writing skills. 
Through this skill, learners can express their personal feelings, opinions or ideas; tell stories; inform or explain; request; converse and discuss; via it, people can display the different functions of language (Ur, 1997).

According to Vilímec (2006), speaking has many roles that must be learned. These roles comprehend the ability to demonstrate skills and knowledge, socially appropriate talk, which is given for appropriate situations. In the past, learners only had a chance to practice the public communication or knowledge demonstration role; teachers talk and students listen. However, students need a complete chance to practice in the full range of communicative roles. The teacher should be more than the talker and the knowledge holder, but instead "the consultant and coach."

According to (Brown, 1997) there are five components of speaking skills, namely comprehension, grammar, vocabulary, pronunciation, and fluency;

1-Comprehension: Engaging effectively in a range of collaborative discussions (one-on-one, in groups, and teacherled)

2-Grammar: Students need to organize a precise sentence during a conversation. This agrees with the description suggested by (Zhang \& Widyastuti, 2010) that student's ability to use structure and differentiate appropriate grammatical rules in a situation.

3- Vocabulary: Students cannot communicate successfully or express their ideas orally or in written form if they do not have adequate vocabulary. So, vocabulary means the appropriate words and phrases that are used in communication.

4- Pronunciation: It is the ability of students to produce language when they speak. It deals with the phonological process that refers to the element of a structure pretended of the elements and principles that decide how sounds differ in a language.

5- Fluency: It is defined as the talent to speak confidently and accurately. Fluency is the main goal of many language students. Fluency includes a rationally speed of speaking and a limited number of pauses. These symbols indicate that students have fluency of speaking and do not have too much time to choose the language items, vocabulary in order to express the message.

For Littlewood, (2007) there are some speaking problems that teachers can come across in getting students to talk in the classroom. These are: inhibition, lack of topical knowledge, low or uneven participation and mother-tongue use. The first problem that the students often encounter is inhibition. When students try to say things in a foreign language in the classroom they are often inhibited. They are worried about making mistakes, fearful of criticism or losing face. They are shy of the attention that their speech attracts. Another problem in speaking class is that participation is low or uneven. In a large group, each student will have very little talking time because only one participant can talk at a time so that the others can hear him/her. There is a tendency of some learners to dominate while others speak very little or not at all. Similarly, that student who can speak English well may have greater chance for further education, of finding employment and gaining promotion (Baker \& Westrup, 2003).

\section{Active Learning}

Active learning is defined as instructional techniques that place the responsibility of learning on learners. It has gained considerable attention in kids' education (Auster \& Wylie, 2006). It is considered as a means of helping students become engaged in the learning process. In addition, it generates classroom settings where learners can not only acquire knowledge and information but also apply them in ways similar to those they will face in their career. So, this pedagogical technique is accomplished through language skills such as; talking, reading, writing, and reflecting (Prince, 2004). The two major theories that have been commonly used to identify teaching and learning processes during the last half century are "Information Processing" or "Objectivism" which is often referred to as "traditional teachercentered instruction" and "Constructivism" which is often referred to as "student-centered instruction." (Heriot,2008). Bonwell \& Eison (1991) proposed that "active approach" to learning launched the theoretical foundation of the active learning movement. Examples of active learning techniques can be included in discussions via classroom and case studies, short written exercises, role-playing, games, hands-on activities, debates, academic service learning, experimental learning, and discovery learning.

As for benefits of active learning strategies, Gallagher \& Reid (2002) mentioned that they may generate greater students' interest and motivation than traditional lecture, involve students in learning process activities rather than just passive listening, provide more frequent and immediate feedback to learners, promote development of student skills in critical thinking, improve writing and speaking skills and even recall of information, promote greater academic achievement, provide students with an opportunity to think, talk and process course material, contribute to more favorable attitudes toward learning, place more emphasis on the role of the teacher as a designer and facilitator of learning experiences rather than an imparter of knowledge, emphasize student-centered learning and develop expertise in collaborative learning and teamwork. 
Concerning bases of active learning, they are as follows; they encourage contacts between students and the teachers, ameliorate cooperation and reciprocity and among students, give immediate feedback, emphasize time on task and respects diverse talents and ways of learning (Wankat, 2002).

Ranjanie (2008) justified reasons for using active learning strategies; Active learning proved its effectiveness in various studies in general and in EFL in particular. Also, it increases learner's engagement in learning, makes it more enthusiastic, raises students' self-esteem and strongly motivated. Furthermore, it maintains strong positive relations among students. Hence, the students have positive attitudes toward the school and teachers. In the process of active learning, students transfer from being passive recipients of knowledge to being active participants in activities that comprehend analysis, synthesis and evaluation. Furthermore, it develops values, attitudes and skills. In the same respect, students do not learn much by just sitting in class listening to teachers, memorizing prepackaged assignments, and spitting negatively given out answers. Also, they added that learners must talk write about what they are learning, and they must make what they learn part of themselves.

\section{Using Active Learning strategies in the classroom}

Bogart (2009) asserts that there are many active learning strategies which can be designed to encourage independent learning for the students in the classroom. Among active learning strategies are:

\section{Brainstorming}

Isaksen (1998) portrayed it as a large or small group activity, which encourages children to focus on a topic and contribute to the free flow of ideas. The teacher may begin by posing a question or a problem, or by introducing a topic. Students then express possible answers, relevant words and ideas.

\section{Role Play}

This strategy is utilized for (a) arousing student interest and engagement, (b) providing a realistic and relevant way for students to connect essential course content to their personal and/or professional lives, (c) teaching students to develop and apply critical thinking skills, (d) creating opportunities for knowledge transfer as well as developing deeper selfawareness and understanding, and (e) helping students develop increased empathy for others and a valuing of and respect for cultural diversity (Richard, 2003).

\section{Simulation}

An elaborate role-play activity is often called simulation. Simulations can introduce an element of realism into teaching, so it is very similar to role-play, where students can bring items to the class to create a realistic environment. (Petty, 2009).

\section{Cooperative learning}

It is a successful teaching strategy in which small teams, each with students of different levels of abilities, use a variety of learning activities to improve their understanding of a subject. Each member of a team is responsible not only for learning what is taught but also for helping teammates. (Johnson \& Johnson, 2009).

\section{Creating field trips (real, simulated or virtual)}

Taking students outside of the traditional classroom on a carefully designed educational field trip is one of active learning strategies. On a foundational level, field trips offer the obvious opportunity for students to create strong authentic connections between oftentimes-abstract academic material and their own life experiences. For example, under the direction of a creative instructor, a short and simple walking tour around campus can provide a wealth of educational opportunities to illustrate concepts previously presented only through textbook readings and/or in-class presentations (Eison, 2010).

\section{Literature Review}

\section{Previous studies on speaking skills}

Kasap (2005) discovered the effect of utilizing active learning on developing students' speaking skills and teachers' perceptions of active learning. Interviews and oral tests were used to gather a lot about control and experimental groups. The participants of the study were forty-five students. They were exposed to a pre and post oral tests. The researcher used questionnaires to the experimental group and interviews to measure teachers' perceptions of Active Learning strategies. The data gathered from the oral tests and questionnaires were examined quantitatively, but the data gathered from the data from interviews were examined qualitatively. The findings of this study may instigate EFL teachers to adapt some of the Active Learning strategies in teaching speaking skills in the usual course book, according to a more active approach, as it helps them to participate in practicing the language and assist them to improve their speaking skills. 
Murad \& Smadi (2009) explored the effectiveness of active learning on language teaching to develop Palestinian elementary students' speaking skills and their attitudes towards speaking English. The sample of ninety-one students chosen from Bueina- Nujidat and Tamra High Schools. The researchers designed a pre and post test to measure the effect of the active learning program in improving the speaking skills of the experimental group. In addition, the researchers designed an instructional program based on active learning teaching and a rubric for assessing students' performance in speaking skills before and after the experimentation.

The study of Abdelrahman (2013) aimed to evaluate the effectiveness of using online oral diaries on speaking proficiency of EFL Saudi First year school students. The sample of this study consisted of four classrooms, one male and one female as the experimental group and one male and one female as the control group. The researcher developed speaking proficiency test and applied it for the control and the experimental groups as a pre-test to make sure that the two groups are equivalence; and also used as a post-test to measure the differences between the two groups. The results of the post-administration of the speaking proficiency test showed there was a significant difference between the mean scores of the experimental group and the mean scores of the control group supporting the experimental group.

Chou (2013) mentioned that English education has been officially incorporated into elementary-level education in Taiwan since 2001, with the key objective of reinforcing pupils' oral communication in class. Although oral interaction involves a degree of speaking output from interlocutors, speaking has unfortunately remained a marginalized area in Taiwanese elementary education. Little is known about how to improve young learners speaking and listening skills in Taiwanese contexts. The present study was carried out with 52(11-years-old) elementary school pupils in Taiwan. An English course was designed to integrate pupils speaking skills into an active learning course with a series of tourism related topics. The results showed that the teaching of speaking skills could be integrated into the active learning course and certain speaking skills were greatly improved. Also, the study has implications for designing an active learning course for teaching and testing speaking skills, as well as for developing listening and speaking abilities among young EFL learners.

Noura, (2013) explored the effect of active learning readiness on speaking ability of the Jordanian intermediate EFL learners. The researcher selected a sample of sixty learners from Alnuzha public school randomly. The sample was divided into two equivalent groups, one as a control and the other as an experimental group. The experimental group was submitted to be taught speaking in light of active learning strategies, while the control group was taught using the traditional methods of teaching. The researcher developed a pre-post oral test to gather the data. The findings of the study revealed that the two groups were statistically significant.

\section{Commentary on the previous studies}

The previous studies reviewed developing speaking skills and its relation to different aspects of teaching language and its effects on language learning. Some studies such as Kasap (2005) utilized active learning strategies. (Abdelrahman, 2013) dealt with using online oral diaries with speaking proficiency. Nouraliyan (2013) impacted the effectiveness of active learning on speaking ability. Murad \& Smadi (2009) explored the effect of task-based language teaching program on developing the speaking skills.

\section{Previous studies on active learning strategies}

Lopez (2003) conducted an experiment based on active learning strategy instead of presentation-practice-production (PPP) approach for teaching English in two classes in a private school in the south of Brazil. He found that students using active learning strategy learned English more effectively because they were using the language to do things- to access information, solve problems, and to talk about personal experiences. The students who were exposed to real language were able to deal with real life situations when they encountered them outside the classroom. He also concluded that teachers who come from a different background, as far as teaching approaches are concerned, should be trained before using Active Learning Strategy in the classroom.

Muller (2005) introduced active learning strategy to a small class of weak students at a private English school in Japan, for the purpose of the study; he adapted a vocabulary-focused lesson from the textbook that he was using and adopted Willis's (1996) task structure in his classes as follows: Performing a communicative task, planning a report of the performance, and reporting the task results to the class. For integrating tasks with a clear link to each unit of the textbook, Muller listed vocabulary from each textbook unit, assigned topics to the vocabulary lists, listed tasks following Willis's (1996) task-types and decided in which weeks each unit would be covered. He concluded that although the task and the subsequent planning and report stages did not fulfill the criteria or features of task-based lessons found in literature, his approach did not show how TBL could be used as a starting point for use with low-level learners who may not be ready for the full version. 
As these students progressed they would gradually be able to tackle tasks, planning, and reporting sessions that are less restricted and more demanding while working with the familiar task- plan- report framework.

Mustafa, (2006) investigated the effects of active learning on foreign language self-concept and reading comprehension achievement. This research was carried through an experimental design with experimental and control groups. In the spring term of 2005-2006 academic year, 100 kindergarten Palestenian students formed the experiment and the control groups which were all randomly chosen. Active learning techniques were applied to experimental groups for thirteen weeks while the control groups were educated through traditional methods in teaching English. The data of the research were collected by the Foreign Language Self-Concept Scale which is developed by the researcher and a reading comprehension placement test. The results demonstrated that the researcher-mediated learning environment, i.e. the group engaged in active learning techniques was successful in enhancing reading comprehension achievement. On the other hand, the effect of active learning on foreign language self-concept was found to be insignificant. Furthermore, there was no significant correlation between foreign language self-concept.

Güneylil (2008) in his research, the effectiveness of active learning approach in native language education has been emphasized. This research was experimental and was used by Turkish teaching organized by active learning approach for determining learning levels of the students concerning their reading comprehension skills. Data had been obtained by utilizing Turkish Reading Comprehension Skill Test. The research was conducted at fifth class level in Şehit Tuncer and Geçitkale primary schools by getting permission from Ministry of Education and it lasted for fourteen weeks in the second term of 2005-2006 education semester. The results of the study indicated that the active learning approach was more effective than the traditional approach.

Ashraf (2011) attempted to investigate the effectiveness of using active learning strategies in teaching vocabulary on developing the fifth graders' speaking and writing skills and on their attitudes towards EFL. Eighty five graders were chosen from a larger population enrolled in the public primary school in Bani Hamad, Minia. They were divided into two groups: an experimental group and a control one, each group included forty pupils. The study followed the prepost experimental design where the experimental group was taught using the active learning program while the control group was taught following the plan prescribed by the Ministry of Education in Egypt. Results of the study revealed that the experimental group significantly surpassed the control one on the post test of speaking, writing, and attitude scale. It was concluded that using active learning strategies in teaching vocabulary helped students develop their speaking skills, writing skills and their attitude towards EFL.

\section{Commentary on the previous studies}

Considering the aforementioned studies, it is apparent that active learning strategy has a significant, positive impact on developing students' language learning. A wide range of evidence has supported the hypothesis that active learning students achieve higher conceptual understanding compared to other students who studied the same courses in the traditional learning approach. It has been concluded that this method is effective in teaching/learning process especially TEFL because it helps the teacher to create students' engagement. Some studies such as Mustafa (2006) devoted themselves to examine the effect of active learning strategies on developing the students' reading skill. Others like Ashraf's (2011) investigated the effect of active learning strategies on developing students' writing skills. Another important issue that is deserved to be mentioned concerning the previous studies is the homological results, since all the previous studies showed positive effect of using active learning strategies on developing students' learning and achievement as well.

\section{Statement of the Problem}

Through reviewing the literature, it becomes apparent for the researcher that a great number of researchers dealt with speaking skills in their studies such as (Wilson, 1997; Doddington, 2001; Zulpahmi, 2014, Abd El-Wahab, 2015). Based on the results of the previous studies and results of the pilot study, the present study can be stated as follows: kindergarten students' level in speaking needs to be improved as they suffer a lot and need remedy for their low practices in the mentioned field. Therefore, the present study will investigate the effect of using a program based on active learning strategies in developing EFL Saudi Kindergarten students in Saudi Arabia

\section{Questions of the study}

In order to tackle this problem, the present study aimed at investigating the impact of using a program based on active learning strategies on developing speaking skills among the Saudi kindergarten students in Saudi Arabia.

This study will attempt to answer the following questions:

What is the effectiveness of using a program based on active learning strategies to develop speaking skills of the Saudi kindergarten students in Saudi Arabia? 
For research purposes this main question can be subdivided into the following questions:

1. What are the required speaking skills for the Saudi kindergarten students in Saudi Arabia?

2. How far do the Saudi kindergarten students in Saudi Arabia master speaking skills?

3. What are the features of using a program based on active learning strategies to develop speaking skills of the Saudi kindergarten students in Saudi Arabia?

4. What is the effectiveness of using a program based on active learning strategies on developing speaking skills of the Saudi kindergarten students in Saudi Arabia?

\section{Purposes of the study}

This study attempted to:

1. Identify the speaking skills necessary for the EFL Saudi kindergarten students in Saudi Arabia

2. Assess the current level of the EFL Saudi kindergarten students in Saudi Arabia in the identified speaking skills.

3. Determine the effectiveness of using a program based on active learning strategies on developing the English speaking skills of the Saudi kindergarten students in Saudi Arabia.

\section{Methodology}

\section{Design}

This study employed the quasi-experimental design in terms of dividing the sample of the study into two groups, an experimental group and a control group. The experimental group would be taught English speaking using the program of active learning strategies and the control group would be taught using traditional methods.

\section{Population and Sample}

The pouplation is all the phenomena subjects studied by the researcher (Milhim, 2002).Population of this study included all kindergarten female children for the school year (2016-2017) in Riyadh city in Saudi Arabia.As for the study sample it was (150) children (75) in the experimental group and (75) children in the control group at Al-Rawwad National Kindergarten school .

\section{Equivalence of the Groups}

Before conducting the research, the researcher was careful in making equivalence betwenn the two research groups in a number of variables that might affect the dependent variable as follows:

1.Chronical age by month.

2.Father's education.

3. Mother's education.

4.Lack of attention scores at pretest for both groups.Table (1) shows the results.

Table (1) T Value of Equivalented Variables for Experimental and Control Groups

\begin{tabular}{|c|c|c|c|c|c|c|}
\hline Variables & Group & $\mathbf{N}$ & Mean & SD & $\begin{array}{l}\text { Calculated } \mathbf{T} \\
\text { Vale }\end{array}$ & $\begin{array}{l}\text { Tabulated } T \\
\text { value }\end{array}$ \\
\hline \multirow[t]{2}{*}{ Chronical age / Months } & $\mathrm{E}$ & 75 & 121.875 & 7.33755 & \multirow[t]{2}{*}{1.9820} & \multirow{10}{*}{2.23} \\
\hline & $\mathrm{C}$ & 75 & 127.6 & 4.9035 & & \\
\hline \multirow[t]{2}{*}{ Reading material degree } & $\mathrm{E}$ & 75 & 7.875 & 1.7268 & \multirow[t]{2}{*}{0.2210} & \\
\hline & $\mathrm{C}$ & 75 & 7.7 & 1.6227 & & \\
\hline \multirow[t]{2}{*}{ Father's education } & $\mathrm{E}$ & 75 & 8.3250 & 4.4057 & \multirow[t]{2}{*}{1.2844} & \\
\hline & $\mathrm{C}$ & 75 & 6.2 & 3.6147 & & \\
\hline \multirow[t]{2}{*}{ Mother's education } & $\mathrm{E}$ & 75 & 7.125 & 1.5526 & \multirow[t]{2}{*}{0.4970} & \\
\hline & $\mathrm{C}$ & 75 & 6.4 & 3.8643 & & \\
\hline \multirow{2}{*}{$\begin{array}{l}\text { Pre lack of attention } \\
\text { scale }\end{array}$} & $\mathrm{E}$ & 75 & 62.75 & 15.7003 & \multirow[t]{2}{*}{0.26333} & \\
\hline & $\mathrm{C}$ & 75 & 64.3 & 9.0559 & & \\
\hline
\end{tabular}

Results in the above table showed no statistically significant differences between experimental and control groups at ( $\alpha$ $=0.05)$, where calculated $\mathrm{T}$ value was less than tabulated on which is (2.23) indicating that the two groups were equivalent on these variables.

\section{Delimitations}

This study was limited to:

1. A sample of the EFL Saudi kindergarten students in Saudi Arabia

2. Some speaking sub-skills of the EFL Saudi kindergarten students in Saudi Arabia. 


\section{Instruments}

The researcher used the following instruments to tackle the problem of the study:

1- A speaking sub-skills questionnaire to determine the most important speaking sub-skills for the EFL speaking skills of the Saudi Kindergarten Students in Saudi Arabia

2- A pre-post test of EFL speaking skills for the Saudi kindergarten students in Saudi Arabia designed by the researcher to assess participants' improvement in speaking skills.

3- A speaking skills' rubric to score participants' speaking skills during the pre-post test.

4-Speaking Active-learning Program as well-designed activities that aims to develop the skills of speaking of learners, promote their competency based on active learning method.

\section{Speaking test}

The purpose of the speaking test is to assess the participants' speaking skills before and after the implementation of the program of the active learning strategies in order to detect the effect of the program on the participants' speaking skill. The speaking test was designed by the researcher and included oral questions and evaluation rubrics. The oral questions consisted of three types of questions:

- Biographical such as "Where do you live?" and "How large is your family"?

- Guided questions such as "What is your favorite subject?', Why? "Do you like to study English? Why?",

- Open questions such as: "In your opinion, what should the kindergarten do to help you study English?" "Why do you think most Arab kids do not like English?"

The participants were, orally, tested pre and post, tape-recorded by two instructors who evaluated them after each session according to an evaluation scheme which were presented by the researcher. The evaluation rubrics for the speaking test were adopted from Ur (2006) and revalidated by a panel of experts to suit the local context. Table (2) presents the specifications and the weight of fluency and accuracy in the oral social interaction test.

Table (2)The Specifications for the Speaking Skills Test (Adopted from Ur, 2006)

\begin{tabular}{|l|l|l|l|}
\hline Accuracy & Grade & Fluency & Grade \\
\hline Little or no language production & 1 & Little or no communication & 1 \\
\hline $\begin{array}{l}\text { Poor vocabulary, mistakes in basic } \\
\text { grammar, very strong foreign accent }\end{array}$ & 2 & $\begin{array}{l}\text { Very hesitant and brief } \\
\text { utterances, sometimes difficult } \\
\text { to understand }\end{array}$ & 2 \\
\hline $\begin{array}{l}\text { Adequate but limited vocabulary , } \\
\text { makes } \\
\text { obvious grammar mistakes, slight } \\
\text { foreign accent }\end{array}$ & 3 & $\begin{array}{l}\text { Gets ideas across, but hesitantly } \\
\text { and briefly }\end{array}$ & 3 \\
\hline $\begin{array}{l}\text { Good range of vocabulary, occasional } \\
\text { grammar slips, slight foreign accent }\end{array}$ & 4 & $\begin{array}{l}\text { Effective communication in } \\
\text { short turns }\end{array}$ & 4 \\
\hline $\begin{array}{l}\text { Wide vocabulary appropriately used, } \\
\text { virtually no grammar mistakes, native } \\
\text { like or slight foreign accent }\end{array}$ & 5 & $\begin{array}{l}\text { Easy and effective } \\
\text { communication, uses long turns }\end{array}$ & 5 \\
\hline
\end{tabular}

The following procedures were carried out for the preparation and administration of the speaking test:

1. The test was prepared by the researcher and validated by a panel that consists of EFL professors and doctors in the faculty of languages and translation at King Saud University.

2. There was an introductory session for researcher and the EFL instructors who would carry out the test in which they would discuss the questions in the speaking test and the evaluation rubrics to agree on the content and the procedures of the test and its evaluation.

3. The instructors would hold individual sessions with the students who will participate in the study. Then, the teachers would meet each student for ten minutes to be asked questions of the speaking skills test. Each session will be tape-recorded. After each session the instructors would evaluate the student's speaking performance according to the evaluation scheme.

4. All the aforementioned procedures were conducted before and after the implementation of the instructional program.

\section{Procedures of the study}

In order to answer the questions of the study, the study proceeded according to the following steps: 
1. Reviewing the literature and the previous studies related to the features of a program based on active learning strategies and the speaking sub-skills necessary for the Saudi kindergarten students in Saudi Arabia.

2. Choosing the sample of the study randomly and dividing them into an experimental group and a control group.

3- Designing a pre-post speaking test.

4- Presenting it to a jury to identify its appropriateness for the speaking skills and participants' level.

5- Modifying the test according to the jury's opinion.

6- Applying the speaking test to determine its reliability.

7-Designing a speaking rubric and presenting it to a jury to identify its appropriateness for the speaking skills and participant's' level.

8- Administering the pre/post speaking test as a pre test for both the experimental group and the control group.

9-Designing the program and presenting it to the jury to identify the suitability of the program content for the speaking skill, participants' level and the aims of the program in general.

12- Modifying the program according to the jury's opinions.

13- Conducting the program to the experimental group.

14- Administering the pre-post speaking test as a post test on the experimental group and the control group after the program.

15- Scoring and treating the data statistically.

16- Presenting summary, results, conclusion, and recommendation.

\section{Results and Statistical Analysis}

The researcher used the SPSS statistical package to calculate means, standard deviation of the scores. The "t" test value for independent samples of differences between the mean scores of the students in both groups on the pre-post speaking test was used.

\section{Results are reported in terms of the hypotheses and the questions of the study}

\section{Hypothesis one:}

There is a statistically significant difference at $(\boldsymbol{\alpha}=0.05)$ between the mean scores of the post-test of the experimental group and the control group in their speaking skills (vocabulary, pronunciation, comprehension, fluency and grammar) in favor of the experimental group. Table (3) presented the mean scores of the post-test of the experimental group and the control group in their speaking skills. Table(3) the mean scores of the post-test of the experimental group and the control group in their speaking skills This hypothesis was related to the questions of the present study: "What is the effectiveness of the suggested program based on active learning strategies in developing the EFL speaking skills of the Saudi kindergarten students in Saudi Arabia?" In order to test this hypothesis the t-test for two independent groups was used. Results are shown in Table (3):

\section{Table (3) T-Test of the Post Administration of the Pre-post Speaking Test of the Experimental and the Control} Groups

Results in table (3) indicate that the experimental group outperformed the control group in all the speaking sub skills. A closer look at Table (3) revealed that vocabulary, pronunciation and grammar were the most improved sub skills (i.e. mean $=15.67,14.73,11.00$ respectively). On the other hand fluency was the least improved sub skill $($ mean $=10.40)$. However, all differences between the experimental and the control group were significant at $(\boldsymbol{\alpha}=0.05)$. This means that the active learning -based program -among other variables not measured by this study-was effective in enhancing the pupils' speaking skills.

\begin{tabular}{|c|c|c|c|c|c|c|c|}
\hline \multirow{2}{*}{$\begin{array}{l}\text { Speaking skills } \\
\text { dimensions }\end{array}$} & \multirow[t]{2}{*}{ Groups } & \multirow[t]{2}{*}{$\mathbf{N}$} & \multirow[t]{2}{*}{ Mean } & \multirow[t]{2}{*}{ S. Deviation } & \multicolumn{3}{|c|}{$\begin{array}{c}\text { T-test for Equality of } \\
\text { Means }\end{array}$} \\
\hline & & & & & $\mathrm{t}$ & Df & Sig. \\
\hline \multirow{2}{*}{ Vocabulary } & Experimental & 75 & 15.67 & .66089 & \multirow[b]{2}{*}{10.12} & \multirow[b]{2}{*}{74} & \multirow[b]{2}{*}{.05} \\
\hline & Control & 75 & 10.96 & 2.45628 & & & \\
\hline \multirow{2}{*}{ Pronunciation } & Experimental & 75 & 14.74 & 1.04826 & \multirow[b]{2}{*}{6.344} & \multirow[b]{2}{*}{74} & \multirow[b]{2}{*}{.05} \\
\hline & Control & 75 & 11.53 & 2.55604 & & & \\
\hline \multirow{2}{*}{ Comprehensibility } & Experimental & 75 & 10.90 & 1.15520 & \multirow[b]{2}{*}{9.881} & \multirow[b]{2}{*}{74} & \multirow[b]{2}{*}{.05} \\
\hline & Control & 75 & 6.233 & 2.31462 & & & \\
\hline \multirow{2}{*}{ Fluency } & Experimental & 75 & 10.40 & 1.24845 & \multirow[b]{2}{*}{7.043} & \multirow[b]{2}{*}{74} & \multirow[b]{2}{*}{.05} \\
\hline & Control & 75 & 7.167 & 2.18274 & & & \\
\hline \multirow{2}{*}{ Grammar } & Experimental & 75 & 11.00 & 1.05045 & \multirow[b]{2}{*}{8.586} & \multirow[b]{2}{*}{74} & \multirow[b]{2}{*}{.05} \\
\hline & Control & 75 & 7.333 & 2.08993 & & & \\
\hline \multirow{2}{*}{ Total } & Experimental & 75 & 62.70 & 4.12018 & \multirow[b]{2}{*}{9.455} & \multirow[b]{2}{*}{74} & \multirow[b]{2}{*}{.05} \\
\hline & Control & 75 & 43.23 & 10.4969 & & & \\
\hline
\end{tabular}


Figure(1) shows the mean differences between the post administration of the experimental and control group on their speaking test:

Figure (1) Differences in the Mean Scores Between the Experimental and the Control Groups on the Post Administration of the Speaking Test

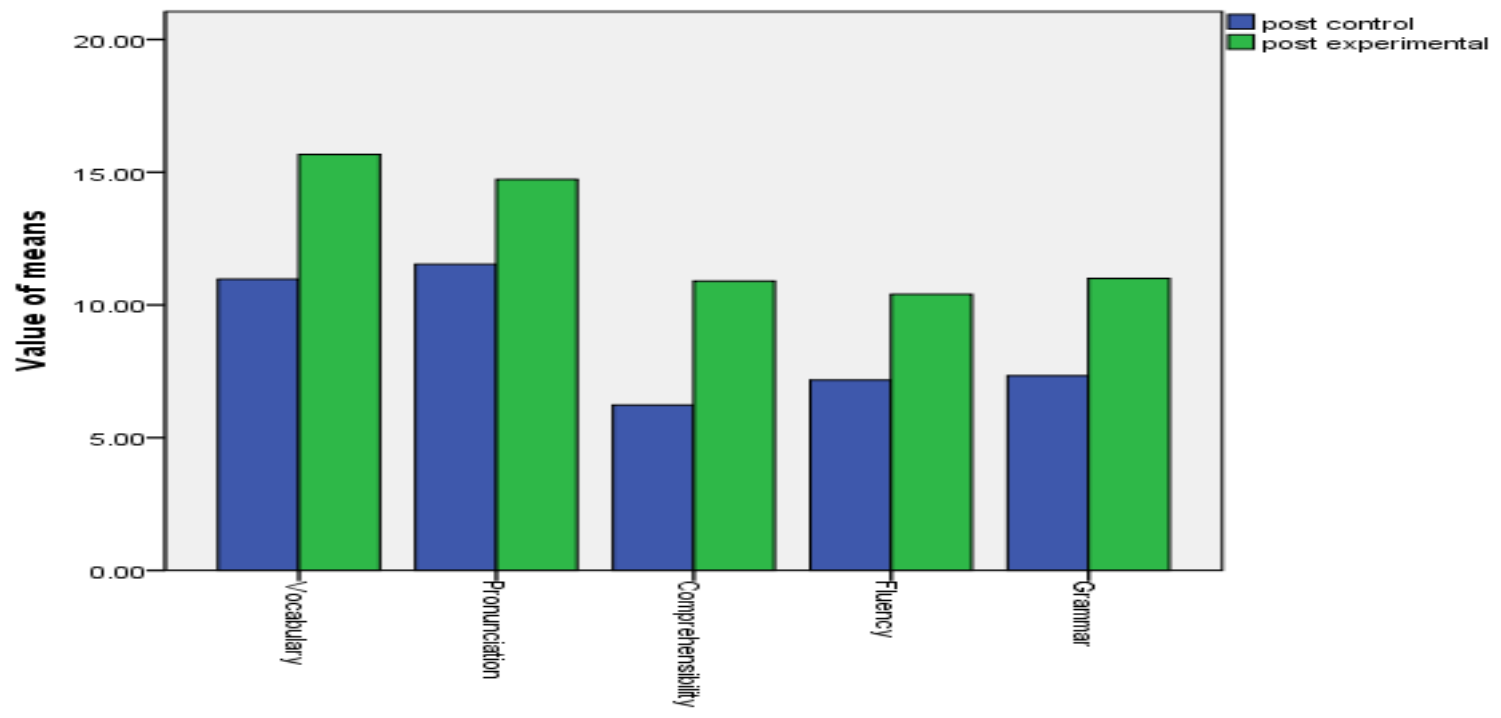

Results revealed for this hypothesis were in line with the results presented in the previous qualitative case study research by many authors, which concluded that active learning strategies improved the EFL speaking skills of the Saudi kindergarten students in Saudi Arabia.

Hypothesis two: "There is a statistically significant difference at $(\boldsymbol{\alpha}=0.001)$ levels between the mean scores of the pre and post-administration of the experimental group in speaking sub skills (vocabulary, pronunciation, comprehension, fluency and grammar) in favor of the post-test"

In order to substantiate this hypothesis the T-test for two independent groups was used. Results are shown in Table (5).

Table (5) T-Test of the Post Administration of the Pre-Post Speaking Test of the Experimental Group

\begin{tabular}{|c|c|c|c|c|c|c|c|c|}
\hline \multirow[t]{2}{*}{ Speaking skills } & \multirow[t]{2}{*}{ Application } & \multirow[t]{2}{*}{$\mathbf{N}$} & \multirow[t]{2}{*}{ Mean } & \multirow[t]{2}{*}{$\begin{array}{c}\text { Std. } \\
\text { Deviation }\end{array}$} & \multirow[t]{2}{*}{$\begin{array}{c}\text { Std. Error } \\
\text { Mean }\end{array}$} & \multicolumn{3}{|c|}{$\begin{array}{c}\text { T-test for Equality of } \\
\text { Means }\end{array}$} \\
\hline & & & & & & $\mathrm{T}$ & $\mathrm{df}$ & Sig. \\
\hline \multirow[b]{2}{*}{ Vocabulary } & Post & 75 & 15.67 & .66089 & .12066 & \multirow[b]{2}{*}{12.917} & \multirow[b]{2}{*}{74} & \multirow[b]{2}{*}{.05} \\
\hline & Pre & 75 & 9.80 & 2.53799 & .46337 & & & \\
\hline \multirow[b]{2}{*}{ Pronunciation } & Post & 75 & 14.73 & 1.04826 & .19139 & \multirow[b]{2}{*}{17.422} & \multirow[b]{2}{*}{74} & \multirow[b]{2}{*}{.05} \\
\hline & Pre & 75 & 8.500 & 1.94316 & .35477 & & & \\
\hline \multirow[b]{2}{*}{ Comprehensibility } & Post & 75 & 10.90 & 1.15520 & .21091 & \multirow[b]{2}{*}{18.936} & \multirow[b]{2}{*}{74} & \multirow[b]{2}{*}{.05} \\
\hline & Pre & 75 & 4.600 & 1.47625 & .26952 & & & \\
\hline \multirow[b]{2}{*}{ Fluency } & Post & 75 & 10.40 & 1.24845 & .22793 & \multirow[b]{2}{*}{13.332} & \multirow[b]{2}{*}{74} & \multirow[b]{2}{*}{.05} \\
\hline & Pre & 75 & 5.033 & 1.67091 & .30507 & & & \\
\hline \multirow[b]{2}{*}{ Grammar } & Post & 75 & 11.00 & 1.05045 & .19179 & \multirow[b]{2}{*}{11.035} & \multirow[b]{2}{*}{74} & \multirow[b]{2}{*}{.05} \\
\hline & Pre & 75 & 6.067 & 2.12018 & .39518 & & & \\
\hline \multirow[b]{2}{*}{ Total score } & Post & 75 & 62.70 & 4.12018 & .75224 & \multirow[b]{2}{*}{16.869} & \multirow[b]{2}{*}{74} & \multirow[b]{2}{*}{.05} \\
\hline & Pre & 75 & 43.00 & 8.60633 & 1.5713 & & & \\
\hline
\end{tabular}

Table (5) results revealed that the post-administration was substantially more significant than the pre-administration of the experimental group in all the speaking sub skills on the speaking test and in the total score of the pre-post speaking test.

Table (5) also revealed that comprehensibility; pronunciation, vocabulary, and fluency were the most improved sub skills (i.e. mean $=15.67,14.73,11.00$ respectively). On the other hand grammar was the least improved sub skill (mean $=10.40$ ). However, all differences between the experimental and the control group were significant at 0.001 levels. This means that the active learning based program was effective in enhancing the pupils' speaking skills. 
Table (6) below sheds more light on these differences. A t-test for two dependent groups was used.

Table (6) T-test Comparing the Pre/post Administration of the Speaking Test for the Experimental Group

\begin{tabular}{|c|c|c|c|c|c|c|c|}
\hline Speaking skills & Application & $\mathbf{N}$ & $\begin{array}{l}\text { Compared } \\
\text { Mean }\end{array}$ & $\mathbf{T}$ & df & $\begin{array}{l}99 \% \\
\text { Interval } \\
\text { Difference } \\
\text { Lower }\end{array}$ & $\begin{array}{c}\text { Confidence } \\
\text { of the } \\
\text { Upper } \\
\end{array}$ \\
\hline \multirow[b]{2}{*}{ Vocabulary } & post & 75 & \multirow[b]{2}{*}{5.567} & \multirow[b]{2}{*}{12.917} & \multirow[b]{2}{*}{74} & \multirow[b]{2}{*}{4.6148} & \multirow[b]{2}{*}{7.1186} \\
\hline & pre & 75 & & & & & \\
\hline \multirow[b]{2}{*}{ Pronunciation } & post & 75 & \multirow[b]{2}{*}{6.233} & \multirow[b]{2}{*}{17.422} & \multirow[b]{2}{*}{74} & \multirow[b]{2}{*}{5.2472} & \multirow[b]{2}{*}{7.2195} \\
\hline & pre & 75 & & & & & \\
\hline \multirow[b]{2}{*}{ Comprehensibility } & post & 75 & \multirow[b]{2}{*}{6.300} & \multirow[b]{2}{*}{18.936} & \multirow[b]{2}{*}{74} & \multirow[b]{2}{*}{5.3829} & \multirow[b]{2}{*}{7.2171} \\
\hline & pre & 75 & & & & & \\
\hline \multirow[b]{2}{*}{ Fluency } & post & 75 & \multirow[b]{2}{*}{5.367} & \multirow[b]{2}{*}{13.332} & \multirow[b]{2}{*}{74} & \multirow[b]{2}{*}{4.2572} & \multirow[b]{2}{*}{6.476} \\
\hline & pre & 75 & & & & & \\
\hline \multirow[b]{2}{*}{ Grammar } & post & 75 & \multirow[b]{2}{*}{4.933} & \multirow[b]{2}{*}{11.035} & \multirow[b]{2}{*}{74} & \multirow[b]{2}{*}{3.7011} & \multirow[b]{2}{*}{6.1656} \\
\hline & pre & 75 & & & & & \\
\hline \multirow[b]{2}{*}{ Total score } & post & 75 & \multirow[b]{2}{*}{28.700} & \multirow[b]{2}{*}{16.869} & \multirow[b]{2}{*}{74} & \multirow[b]{2}{*}{24.011} & \multirow[b]{2}{*}{33.39} \\
\hline & pre & 75 & & & & & \\
\hline
\end{tabular}

It is evident from table (6) above that

1. Values of differences between the mean score were $(4.933 ; 5.367 ; 5.567 ; 6.233 ; 6.300)$ and $(28.700)$ for the total score respectively. The greatest value was in the "Comprehensibility" and the total test score and the least was in the "grammar" and "fluency" sub-skills.

2. The (Zero) value is found outside the confidence interval of all differences for all the speaking sub skills and for the total test score as well. These results support the significance of the t-test values for the differences between the pre and post speaking test for the experimental group. Table (7) below illustrates the effect size of using the active learning -based program on developing the pupils' speaking skills using Eta Squared.

Table (7) The Effect Size of the Training Program in the Experimental Group's Pre-Post Speaking Skills' Test

\begin{tabular}{lcc}
\hline Speaking skills & Partial Eta Squared & Effect size \\
\hline Vocabulary & .852 & Large \\
Pronunciation & .913 & Large \\
Comprehensibility & .925 & Large \\
Fluency & .859 & Large \\
Grammar & .808 & Large \\
Total & .908 & Large
\end{tabular}

Table (7) displays that the effect size of the teaching program based on active learning strategies ranged from (40\% $70 \%$ ) on the post-administration of the speaking test for the experimental group. This points to the effectiveness of the program based on active learning strategies (among other variables not included in the current study such as school environment, private tutoring, etc) in improving the experimental group speaking skills.

\section{Results of the study}

The present study reached the following results

1. There was no statistically significant difference between the mean scores of the pre-test of the experimental group and the control group in their speaking skills.

2. There was a statistically significant difference at 0.05 level between the mean scores of the post-test of the experimental group and the control group in their speaking skills in favor of the experimental group.

3. There was a statistically significant difference at 0.001 level between the mean scores of the pre-test and the posttest of the experimental group in speaking skills in favor of the post-test.

4. There was a statistically significant difference at 0.001 level between the mean scores of the pre- and postadministration of the experimental group in the speaking EFL motivation scale in favor of the post-test. 
To conclude; with reference to the results of this study concluded that using a program based on active learning strategies can enhance EFL Saudi kindergarten students in Saudi Arabia speaking skills.

\section{Recommendations}

Based on the results and conclusions of the study, the following recommendations are suggested:

1. Ministry of Education should train EFL teachers on using active learning strategies, in order to help their students to learn EFL speaking skill more efficiently.

2. Course designers should consider the inclusion of active learning strategies when developing EFL courses especially at kindergarten stage.

3. Faculty of Education should train in-service teachers on the different kinds of strategies, especially active learning strategies.

4. EFL teachers should hold workshops, seminars and conferences to share experience and views on teaching and using active learning strategies.

\section{Suggestions for further research}

The following points are recommended to be considered for further research:

1. This study can be replicated at a different level in education and with larger samples.

2. Exploring the use of active learning strategies in developing other language skills.

- This is a research project that was supported by a grant from the Research Center for the Humanities, Deanship of Scientific Research at King Saud University, 2017

\section{References}

Tg Ainul,R., Chik,A., Sahrir,A., \&Nordin,M. (2017). A review of documentary film as authentic input in enhancing writing skills in ASL setting. Journal of Nusantara Studies, 2, (1), 99-110.

Abdel-Wahab, M. (2015) Utilizing an active learning -based program in developing EFL primary stage pupilse speaking skills and motivation. Unpublished M. A. Degree. Faculty of Education. Mansoura University.

Auster, E. , \& Wylie, K. (2006). Creating active learning in the classroom: A systematic approach. Journal of Management Education, 30 (2), 333-353.

Baker, J., \& Westrup, H. (2003). Essential speaking skills: A handbook for English language teachers. London: Continuum.

Bogart, W. (2009). Developing pedagogy for active learning (PAL) Part I including a brief history of active learning in Thailand. 6TUAcademic JournalU6T. Thammasat University, Bangkok, Thailand Bonwell

Bonwell, C.\& Eison, J. (1991). Active Learning: Creating Excitement in the Classroom. 1991 ASHE-ERIC Higher Education Reports. ERIC Clearinghouse on Higher Education, The George Washington University, One Dupont Circle, Suite 630, Washington, DC 20036-1183

Brown, A. (1997). An investigation of rates orientation in awarding scores in the ILETS oral interview. Cambridge University Press.

Doddington, C. (2001). Entitled to speak: Talk in the classroom. Studies in philosophy and education, 20 (3), 267-47.

Febriyanti, E.(2011). Teaching speaking of English as a foreign language: Problems and solutions. Indonesia Scientific Journal Database, 1 (2), 133-146.

Gallagher, J. \& Reid, K. (2002). The learning theory of Piaget and Inhelder. Lincoln, NE: Authors choice press

Güneyli1, A. (2008). The impact of active learning approach on improving the reading skills in native language teaching. Journal of Language and Linguistic Studies, 4 (2), 66-93.

Harmer, J. (2007). How to teach English. Essex: Pearson Education Limited.

Hasan, A.(2014). The effect of using task-based learning in teaching English on the oral performance of the secondary school students. International Interdisciplinary Journal of Education, 3 (2), 250-264.

Heriot, K., Cook, R., Jones, R., \& Simpson, L. (2008). The use of student consulting projects as an active learning pedagogy: A case study in a production/operations management course. Decision Sciences Journal of Innovative Education, 6 (2), 463-481.

Isaksen, S.(1998). A review of brainstorming research: Six critical issues for inquiry. Buffalo, NY: Creative Research Unit, Creative Problem Solving Group-Buffalo.

Johnson, D., \& Johnson, F. (2009). Joining together: Group theory and group skills. (10th Ed.). Boston: Allyn \& Bacon.

Kasap, B. (2005). The effectiveness of task-based instruction in the improvement of learners' speaking skills (Doctoral dissertation, Bilkent University). 
Littlewood, W. (2007). Communicative language teaching. Cambridge: Cambridge University Press.

Lopez, M. (2003). Three-dimensional clay modeling instruction: A pathway to spatial concept formation in second language learners.

Murad, T., \& Smadi, O. (2009). The effect of task-based language teaching on developing speaking skills among the Palestinian secondary EFL students in Israel and their attitudes towards English. The Asian EFL Journal.

Mustafa, E., Colonel, T., \& Yurdabakan, A. (2012). The effects of active learning on foreign language self-concept and reading comprehension achievement. International Journal for New Trends in Education and Their Implications, 3, 1309-6249.

Nouraliyan, R., Khodahan, D. \& Jahandan, S. (2013). The effectiveness of learning based readiness of EFL learners speaking ability (Islamic Azad university, IJFALS, vol (3), no.(2) April,2013

Nunan, D. (2003). Introducing discourse analysis. London: Penguin English.

Petty, G. (2009).Teaching today: A practical guide. 4th edition. Nelson Thorns, LTD

Prince, M. (2004). Does active learning work? A review of the research. Journal of Engineering Education, 93 (3), 223-231.

Ranjanie, B. (2012). Attitude of middle school teachers towards active learning methodology (ALM) In Theni Dt, Englishnadu. International Journal of Behavioral Social and Movement Sciences, 01 (03), 23-28.

Richards, J., Platt, J. \& Platt, H. (1995). Longman Dictionary of Language Teaching and Applied Linguistics. Harlow: Longman

Ur, P. (1997). A course in language teaching: Practice and theory. Cambridge University Press.

Vilímec, E. (2006). Developing speaking skills. Unpublished Phd dissertation, Pardubice University.

Wankat, P. (2002). The effective efficient professor: Teaching, scholarship and service. Boston, MA: Allyn

Wilson, J. (1997). A Program To Develop the Listening and Speaking Skills of Children in a First Grade Classroom.

Zhang, Y., \& Widyastuti, I. (2010). Acquisition of L2 English morphology. Australian Review of Applied Linguistics, 33(3), 29-1.

Zulpahmi, A. (2014). Improving students' speaking ability by using reciprocal teaching strategy at the twelve grade students of SMKN 1 RAMBAH Rokan HULU Regency. Urnal Ilmiah Edu Research Vol.3 No.1, 123-156.

\section{Web Resources}

Ashraf, M. (2011). The effectiveness of using active learning strategies in teaching vocabulary on developing fifth graders' speaking and writing skills \& on their attitudes towards EFL. Master dissertation, Minia University Faculty of Education. Retrieved Nov. 28 from 6TU http:// main.eulc. edu.eg/eulc _v5/Libraries/Thesis/BrowseThesisPages.aspx?fn= PublicDrawThesis\&BibID=11337162U6T.

Bashir, M., Azeem, M., \& Dogar, A. (2011). Factor effecting students' English speaking skills. British Journal of Arts and Social Sciences, 2 (1). Retrieved from http://www.bjournal.co.uk/BJASS.as px

Chou, M. (2013). International Journal of Listening. Retrieved from: http://www.tandfonline.com/loi/hij120,in February25th, 2017.

Eison, J. (2010). Using active learning Instructional strategies to create excitement and enhance learning. Retrieved from :http://www.cte.cornell.edu,in May23rd,2017.

Kayi, H. (2006). Teaching speaking: Activities to promote speaking in a second language. The Internet TESL Journal, Vol. XII, (11). Retrieved Jun 22, 2017 from http://iteslj.org/Articles/Kayi-Teaching.

Chun, T. (2005). Four skills of language learning: Listening, speaking, reading and writing. .Retrieved on 17-7-2017 at6TUhttp://www.writework.com/essay/four-skills-languageU6T.

Oradee, T. (2012). Developing speaking skills using three communicative activities (discussion, problem-solving, and role-playing). International Journal of Social Science and Humanity, 2 (6), 533-535. Retrieved from http://doi.org/10.7763/IJSSH.2012.V 2.164 